\title{
Suitability Evaluation of Cold Water Paddy Field for Rice Planting
}

\section{in Jianghan Plain}

\author{
Qingjun Deng ${ }^{1, a^{*}}$, Yuru Chen ${ }^{2, b}$ \\ ${ }^{1}$ Wuhan Municipal Engineering Design \& Research Institute Co., Ltd., Wuhan, China \\ ${ }^{2}$ Hubei Geological Survey, Wuhan, China \\ a dengqingjun2007@163.com, ${ }^{\mathrm{b}}$ chenyurugreta@163.com
}

Keywords: suitability evaluation ; cold water paddy field; rice planting.

Abstract.Cold water paddy field is one of the main factors to agricultural production and crop high yield. This paper proposes a suitability evaluation index framework of cold water paddy field for rice planting with site conditions, soil physical and chemical properties, soil nutrient status, social and economic benefits as the first- level index which contains 14 secondary indicators. This research studies and establishes the corresponding calculation method, constructs the comprehensive evaluation index system of suitability, employs analytic hierarchy process (AHP) to accomplish the suitability assessment and zoning of cold water paddy field.

\section{Introduction}

Cold water paddy field refers to a strong gley low-yielding rice paddy, which is long-term impregnated by cold groundwater. It is one of the main types of low-yield paddy soil in southern China. China has about 3.46 million $\mathrm{hm}^{2}$ cold water paddy field that accounts for $15.07 \%$ of national paddy area, and $44.2 \%$ of low-yield paddy area ${ }^{[1]}$. The process of rice growth is closely related to soil permeability, nutritional components, temperature, groundwater depth, groundwater temperature and other factors ${ }^{[2]}$.

This paper analyzes the site conditions, water-soil physical-chemical properties and soil nutrient status, aims to construct the comprehensive suitability evaluation index system for rice planting in cold water paddy field and employ analytic hierarchy process to accomplish the suitability assessment and zoning of cold water paddy field. Meanwhile, this paper analyzes the main unsuitable factors in the rice-growing areas and provides reasonable proposal of transformation and governance to guide for the sustainable development of agriculture in Jianghan Plain.

\section{Introduction to the study area}

\section{Location}

Jianghan plain is located in the middle reaches of the Yangtze River, south-central Hubei province. It is known as the "land of plenty", which is originally an important grain-producing area and agricultural production base, with a total area of about $3.8 \times 10^{4} \mathrm{~km}^{2}$. It is the largest plain in the upper reaches of the Yangtze River.

\section{Hydrogeological characteristics}

Jianghan Plain has numerous rivers and lakes, which is a typical fluvial plain. ${ }^{[3]}$. The water-bearing formation can be divided into three layers: the pore phreatic aquifer, the upper pore confined aquifer, and the lower fracture pore confined aquifer. Main aqueous media are sandy loam 
and silt. Main recharge sources of groundwater are atmospheric precipitation, lateral infiltration recharge of rivers and lakes, and infiltration recharge of irrigation water .

\section{Feature of cold water paddy field}

There is about $9640 \mathrm{~km}^{2}$ cold water paddy field in Jianghan plain, centralized distribution mainly in the southeastern part of the study area and the surrounding area, especially in the southeastern part. The main feature of cold water paddy field is that the water table is shallow, stagnant water soak throughout the year long, soil moisture is saturated, strong reduction, water and soil temperature is low, causing the number of microorganisms dropped in the plow layer, biochemical reaction is weak, the low-yielding fields seriously affecting the growth of the local rice and other crops ${ }^{[4]}$.

\section{Construction of Comprehensive Evaluation System}

\section{Principles and general idea of the construction}

Construction of cold soak field rice cultivation suitability comprehensive evaluation system needs to take the following principles: (1)Quantitative and qualitative principles.(2)Scientific and operational principles $^{[5]}$.(3)Grade construction principles.

The general idea: In the full use of existing monitoring work, combining use of "state pressure - response - action" and "social - economy - environment" research method, hierarchical construct cold soak field rice cultivation suitability comprehensive evaluation framework, and establishment of appropriate calculation methods, building suitability comprehensive evaluation index system, and ultimately macroscopic master variation of the cold soak field, the auxiliary of plans in agricultural production functional areas, to reach the goal of macro-management and decision-making.

\section{Classification of comprehensive evaluation index system}

Cold water paddy field ecological has diversity and multi suitability characteristics, Coupled with the impact of Yangtze River and Hanjiang River erratically running and human activities, so ecological environment of cold soak field in Jianghan Plain has the characteristics of vulnerability. Suitability evaluation system for rice cultivation need to effectively combine the characteristics of cold soak field, according to the type of membership function of each index, calculated for each indicators the appropriate range and inflection to determine suitability evaluation system which are shown in Table 1. The critical value range of the second level indicators index is based on suitability or restrictive for rice growth Index values are character or qualitative description, such as soil texture, etc., for the determination of such indicators, based on long-term production experience to judge, and can be conducive to the type of rice grown identified as critical value bounds. 
Table1 Suitability evaluation index system and classification

\begin{tabular}{|c|c|c|c|c|c|c|}
\hline $\begin{array}{c}\text { The first-level } \\
\text { indicators }\end{array}$ & $\begin{array}{c}\text { The second level } \\
\text { indicators }\end{array}$ & $\begin{array}{c}\text { Eigenvalues } \\
\text { contribution } \\
\text { rate }[\%]\end{array}$ & $\begin{array}{c}\text { The most appropriate } \\
\text { level }\end{array}$ & $\begin{array}{c}\text { Appropriate } \\
\text { level }\end{array}$ & Sub- Appropriate & Inappropriate \\
\hline \multirow{3}{*}{$\begin{array}{c}\text { Site conditions } \\
(\mathrm{S}-\mathrm{C})\end{array}$} & altitude $[\mathrm{m}]$ & 3.539 & $30 \sim 70$ & $70 \sim 110$ & $110 \sim 200$ & $<30 \mathrm{~m}$ \\
\hline & $\begin{array}{c}\text { groundwater } \\
\text { temperature }\left[{ }^{\circ} \mathrm{C}\right]\end{array}$ & 11.308 & $20 \sim 25$ & $16 \sim 20$ & $13 \sim 16$ & $<13$ \\
\hline & groundwater depth[m] & 10.216 & $0.7 \sim 1.0$ & $0.5 \sim 0.7$ & $0.1 \sim 0.4$ & $<0.1$ \\
\hline \multirow{6}{*}{$\begin{array}{c}\text { Soil } \\
\text { physicochemical } \\
\text { properties } \\
\text { (S-P) }\end{array}$} & soil texture & 10.615 & pink sticky clay loam & clay loam & heavy clay & heavy clay \\
\hline & $\mathrm{Ph}$ & 7.367 & $5.5 \sim 6.5$ & $5.0 \sim 5.5,6.5 \sim 7.5$ & $4.5 \sim 5.0,7.5 \sim 8.0$ & $<4.5,>8.0$ \\
\hline & organic matter[\%] & 6.315 & $2 \sim 5$ & $1 \sim 2,5 \sim 8$ & $0.5 \sim 1,8 \sim 12$ & $>12,<0.5$ \\
\hline & $\begin{array}{c}\text { ation exchange } \\
\text { capacity }[\mathrm{Cmol} / \mathrm{kg}]\end{array}$ & 3.547 & $270 \sim 330$ & $\begin{array}{c}220 \sim 270,330 \sim 3 \\
80\end{array}$ & $170 \sim 220,380 \sim 430$ & $<170,>430$ \\
\hline & Conductivity $[\mathrm{ms} / \mathrm{cm}]$ & 4.213 & $0.10 \sim 0.19$ & $0.20 \sim 0.29$ & $0.30 \sim 0.39$ & $0.40 \sim 0.49$ \\
\hline & redox potential[mv] & 4.213 & $>500$ & $300 \sim 500$ & $100 \sim 300$ & $<100$ \\
\hline \multirow{3}{*}{$\begin{array}{l}\text { Soil nutrient status } \\
\qquad(\mathrm{S}-\mathrm{N})\end{array}$} & $\begin{array}{l}\text { alkaline hydrolysis } \\
\qquad \mathrm{N}[\mathrm{mg} / \mathrm{kg}]\end{array}$ & 4.012 & $150 \sim 200$ & $\begin{array}{c}100 \sim 150,200 \sim 2 \\
40\end{array}$ & $50 \sim 100,250 \sim 350$ & $<50,>350$ \\
\hline & available $\mathrm{P}[\mathrm{mg} / \mathrm{kg}]$ & 4.923 & $20 \sim 30$ & $10 \sim 20$ & $5 \sim 10$ & $<5$ \\
\hline & available $\mathrm{K}[\mathrm{mg} / \mathrm{kg}]$ & 5.235 & $100 \sim 150$ & $70 \sim 100$ & $40 \sim 70$ & $<40$ \\
\hline \multirow{2}{*}{$\begin{array}{c}\text { Social and } \\
\text { economic benefits } \\
\text { (S-E) }\end{array}$} & $\begin{array}{c}\text { costs } \\
\text { [Yuan / mu] }\end{array}$ & 4.356 & $<700$ & $700 \sim 850$ & $850 \sim 1000$ & $>1000$ \\
\hline & Output[Yuan / mu] & 3.251 & $>1500$ & $1000 \sim 1500$ & $600 \sim 1000$ & $<600$ \\
\hline
\end{tabular}

\section{Suitability Evaluation}

\section{Sampling methods and data sources}

According cold water paddy field distribution, combined with the evaluation index system, the sampling points are arranged to take the entire areas of methods, basic follow $5 \mathrm{~km} \times 5 \mathrm{~km} /$ points, in a densely populated area around the basic farmland protection areas, rivers and lakes surrounding farmland, polluted areas properly encrypted. The first type is mixed sample of cold soak rice field, the second is near the cold soak field sampling point and its parent materials the same to high yielding paddy soil, immediately after retrieving soil samples back to the laboratory, the determination of iron content with the status quo wet soil in accordance with the relevant normative standards in the room, with air-dried soil laboratory analysis of soil organic matter, total N, alkaline hydrolysis $\mathrm{N}$, available $\mathrm{P}, \mathrm{K}$, exchangeable $\mathrm{Ca}$ exchangeable $\mathrm{Mg}$, cation exchange capacity and the conventional water-soluble salt ions, heavy metals and other indicators.

\section{Evaluation of cell division}

Utilization of GIS overlay function, topography map of the study area, sampling points distribution map, hydrogeological zoning maps, land use maps and Jianghan Plain administrative map were superimposed to form a 132 evaluation unit .

\section{Suitability evaluation methods and index weights}

Cold soak field Suitability assessment aims to reveal suitability and restrictive for rice cultivation in the Jianghan Plain, provide the basis for rational exploitation and transformation of cold soak field. 
Adopted AHP to determine the influence degree of each index on the suitability assessment. according to the hierarchy, comparing the relative importance of the same level of each indicator to the previous level, forming the judgment matrix, through sorting the level and consistency test, calculates the index level for the right to re-target layer. While taking advantage of Delphi (DELPHI) consulting method obtained the right to normalized sample data that were multiplied by the correction process, re-use guidelines layer weights multiplied by the corresponding weight of the secondary indicators to seek a comprehensive weights.

\section{Results and Analysis}

Based on the sampling points of data and evaluation unit with the GIS and Kriging interpolation method, it evaluates suitability of cold water paddy field and partition . The most suitable area for $1012.2 \mathrm{~km}^{2}$, the proportion of $10.5 \%$; suitable area for $3962.04 \mathrm{~km}^{2}$, the proportion of $41.1 \%$, distributed in most of the studied area ; less suitable area for $3007.7 \mathrm{~km}^{2}$, the proportion of $31.2 \%$, distributed in the study area and the surrounding area of four Lake and post-like plains; unsuitable area for $1658.1 \mathrm{~km}^{2}$, the proportion was $17.2 \%$. Overall, the suitable for planting rice fields accounted for 51.6 percent of total cold soak, it can support agricultural production in general.

The main factors include natural factors and human activities in less suitable and unsuitable areas. Related indicators met or exceeded the the critical value for normal growth of rice, and it becomes an obstacle factor of low-yielding for cold soak flied. Due to the complexity of the geological environment, cold soak field is ultimately a problem of groundwater and soil environmental problem, so it has difficulty in improving its regulation in the less suitable and unsuitable area. It should be based on existing groundwater and soil monitoring network, taking the particularity of cold soak fields into account, to lay a comprehensive monitoring network,grasp the dynamic changes provide guidance for the rational development and utilization of cold soak field.

\section{Conclusions and Recommendations}

(1) The use of "state - pressure - response - action" and "social-economic-environment," comprehensive research methods, established a suitability evaluation index system of cold water paddy field for rice planting in Jianghan Plain, The suitability evaluation index system provides favorable guidance for suitability and limitation degree of rice cultivation.

(2) According to suitability assessment results, cold soak field can meet the needs of agricultural production on the whole. It needs to establish a comprehensive monitoring network to better grasp the dynamic changes of cold soak field.

(3) Unsuitable for agricultural production of cold soak field, related transformation and control measures is needed to be taken to be better serve the agricultural production. But the development of remediation should be taken seriously, it is made into lake or developed into water and land-based pond mode, or it takes a great effort into productive farmland should be depended on the local socio-economic conditions, not blindly.

\section{References}

[1] Juanjuan Chai, Mi Liao, Peizhi Xu et al. Feature Analsis on Nutrients Restrictive Factors of Major Low Productive Waterlogged Paddy Soil in China [J].Journal of Soil and Water Conservation, 2012, 26( 4):284-288(in Chinese).

[2] Zhangyong Liu, Baitao Liu, Lie Xie et al. The Features And Appraise Index System Of 
Agricultural Ecological Environment Of The Waterlogging Land In Jianghan Plain[J]. Resources and Environment in the Yangtze Basin, 2003,1(12):83-87(in Chinese).

[3] Tiancheng Ai, Fangmin Li, Xiongren Yuan.Evaluation of Soil Chemical Characteristics and Fitness of Lake Sedimentary Waterlogged Land in Jianghan Plain[J]. Journal of Hubei Agricultural College, 2004,12(4):245-247(in Chinese).

[4] Jiaoguo Jiao, Huijuan Zhang, Dalian He.Characteristics and Amelioration Measures of Cold Spring Paddy Soils in China[J].Journal of Anhui Agri, Sci. 2012,40(7):4247-4248(in Chinese).

[5] Aijun Li, Xiang Zhu, Biyun Zhao.Preliminary study on construction of indicator system of dynamic monitoring and assessment of ecoenvironments[J]. Environmental Monitoring in China, 2004,20(4):35-38(in Chinese). 